$\begin{array}{lll}\text { Makalenin Türü / Article Type } & : \text { Araştırma Makalesi / Researh Article } \\ \text { Geliş Tarihi / Date Received } & : 23.10 .2018 & \\ \text { Kabul Tarihi / Date Accepted } & : 15.10 .2019 & \\ \text { Yayin Tarihi / Date Published } & : 31.10 .2019 & \\ \text { doi) https://dx.doi.org/10.17240/aibuefd.2019..-473905 } & \end{array}$

\title{
ÖĞRETMEN ADAYLARININ DUYGU DURUMLARININ FARKLI SINIFLAMALARA GÖRE INCELENMESI
}

\author{
Kamil YILDIRIM ${ }^{1}$, Hasan TABAK ${ }^{2}$
}

\section{ÖZ}

Öğretmen adaylarının duygu durumlarını farklı sınıflandırmalarla betimlemeyi amaçlayan bu çalışma Aksaray Üniversitesi Eğitim Fakültesinde farklı programlarda öğrenim gören toplam 695 öğretmen adayı üzerinde gerçekleştirilmiştir. Çalışmanın verileri araştırmacılar tarafından geliştirilen duygu durum ölçeği ile toplanmıştır. Verilerin analizinde betimleyici istatistiklerden, açımlayıcı ve doğrulayıcı faktör analizlerinden yararlanılmıştır. Çalışma sonunda öğretmen adaylarının olumlu duyguları olumsuz duygulara göre daha yoğun yaşamakla birlikte her iki duygu türünü de çok az düzeyinde yaşadıkları belirlenmiştir. Öğretmen adaylarının en yoğun yaşadıkları duygular merhamet, sevgi ve can sıkıntısı olarak saptanmıştır. Bu çalışmanın en önemli sonucu katılımcı öğretmen adaylarının duygusal bakımdan henüz öğretmenlik mesleğine hazır olmadıklarının belirlenmiş olmasıdır. Araştırmada elde edilen sonuçlar farklı duygusal sınıflandırmalar, kültürel tipolojiler ve beş büyük karakter açısından tartışılarak uygulamacılara ve araştırmacılara yönelik öneriler geliştirilmiştir.

Anahtar Kelimeler: Duygu durum, öğretmen adayları, sınıflama, AFA, DFA

\section{EXAMINING EMOTIONS OF TEACHER CANDIDATES REGARDING DIFFERENT CLASSIFICATIONS}

\begin{abstract}
This study, which aims to describe the emotions of prospective teachers from different perspectives, was conducted on a total of 695 teacher candidates studying in different programs at Aksaray University Faculty of Education. The data of the study were collected by the emotion scale developed by the researchers. In the analysis of the data, descriptive statistics, exploratory and confirmatory factor analyzes were used. At the end of the study, it was determined that pre-service teachers experience positive emotions more intensely than negative emotions, but both emotion types lived at a very low level. The most intense experiences of pre-service teachers were determined as compassion, love and boredom. The most important result of this study is that it was determined that the participant teacher candidates were not emotionally ready for the teaching profession. The results of the study were discussed in terms of different emotional classifications, cultural typologies, and five major characters, and suggestions for practitioners and researchers were developed.
\end{abstract}

Keywords: Moods, teacher candidates, classification, EFA, CFA

\footnotetext{
${ }^{1}$ Aksaray Üniversitesi, Eğitim Fakültesi, kamilyildirim@aksaray.edu.tr, (1) https://orcid.org/0000-0002-5212-3905

${ }^{2}$ Aksaray Üniversitesi, Eğitim Fakültesi, hasantabak@gmail.com, 는tps://orcid.org/0000-0003-3923-5133
} 


\section{GİRIŞ}

Duygular, insanı harekete geçmeye yönelten dürtülerdir (Goleman, 2011). Birey, iç ve dış çevresinden gelen uyaranlar sebebiyle kendisi ve çevresindeki başka kişi, nesne ya da olaylara yönelik hissi tepkiler oluşturmaktadır (Çoruk, 2012; Kervancı, 2008). Duygular oldukça geniş bir alanda bireyin ve çevresindekilerin yaşam kalitesini etkilemektedir. Akademik başarıda, iş performansında, mesleki edinimlerde, sağlıklı uzun bir ömür sürmede ve bireysel-toplumsal iyi oluş hali üzerinde duyguların etkileri belirlenmiștir (Chernyshenko, Kankaraš, ve Drasgow, 2018). Bireyin duygu durumu onun davranışlarına yansıyarak iş arkadaşlarını, performansı ve buna bağlı örgütsel sonuçları etkilemektedir (Akçay ve Çoruk, 2012).

Duygular, bireyin alacağı kararın niteliğini ve performansını da etkilediğinden (Akdoğan, 2016; Li ve Ahlstrom, 2016) yönetimin çalışma alanına girmektedir. Yönetimsel müdahaleler ile çalışma ortamlarında çalışanın performansına olumlu katkıları olan duyguları yaşamaları sağlanabilir (Robbins ve Judge, 2015). Benimsenen yönetim anlayışı ve bireye yönelik tutum, örgütün duygusal iklimini etkileyebilmektedir (Töremen ve Çankaya, 2008). Çalışma ortamında olumlu duygusal iklimin oluşturulmasında başlıca sorumluluk yönetici ve liderlere düşmektedir. Liderlik niteliklerinden biri takipçilerin duyguları aracılığıyla onları harekete geçirebilmektir. Örgütsel davranışları yönetebilmek için öncelikle duygu durumları bakımından çalışanlar tanınmalıdır (Akçay ve Çoruk, 2012; Lunenburg ve Ornstein, 2013).

Duyguların temelinde algılama, hafıza, muhakeme gibi bilişsel süreçler olsa da organizmanın uyaranlara yönelik ilk tepkilerinin, duyuşsal tepkiler olduğu ve bunu bilişsel tepkilerin izlediği açıklanmaktadır (Chernyshenko vd., 2018). Örneğin tehlike anında önce duyuşsal tepkiler verilmektedir. Toplumsal ilișkilerde önem verilen bir konuyla ilgili tehdit algısı da duyuşsal tepkileri tetiklemektedir. Yaşanılan duygular içinde yaşanılan koşullara bağlıdır ve çevresel koşullara yönelik bir tepki ve aynı zamanda birer göstergedirler. Murphy ve Hall'a (2011) göre duygular ve zihinsel süreçler arasında dinamik bir etkileşim bulunmaktadır. Bundan dolayı bir alandaki gelişim diğer alana da pozitif etki yaratmaktadır. Örneğin duygusal bakımdan gelişmiş birinin zihinsel becerilerinin de gelişmiş olduğu söylenebilir. Dolayısıyla bir alandaki durum farklı alanlar (zihinsel, duygusal ve sosyal) hakkında da bilgi sağlar. Farklı uyaran veya yaşantı, kişide farklı şiddette duygusal tepkilere yol açmaktadır. Kişilerin duygusal eşikleri farklı olduğundan onların benzer uyaranlara gösterdikleri duygusal tepkiler de farklı olabilmektedir (Li ve Ahlstrom, 2016). Duygusal tepkiler, kapsamlı algısal ve bilișsel kodlama olmaksızın, bilişsel yargılardan daha erken gerçekleşebilir (Zajonc, 1980). Robbins ve Judge (2015) duyguyu, bir kişiye ya da bir şeye yönelik kısa süreli fakat yüksek yoğunluklu his olarak tanımlamaktadırlar. Eğer bu his çeşitli nesne, olay ya da kişiye yaygınlaştırılan düşük yoğunluklu fakat uzun süreli ise bu durumu duygulanım şeklinde tanımlamışlardır. Duygu, yaşandıktan sonra daha uzun süreli olan duygulanıma dönüşerek, belli bir olaya, nesneye ya da kişiye yönelik istikrarlı bir tepki haline gelebilir. Bundan dolayı deneyimler, belirli duyguların yerleşmesine ve belirli duygusal tepkilere yol açabilir. Örneğin bir öğrenciye tavrınızdan dolayı sizi eleştiren meslektaşınıza kızgınlık duyabilirsiniz. Bu duygunuzu besleyen başka deneyimler sebebiyle, kızgınlık duygunuz başka olay, kişi ve nesnelere yayıldığında bu durum duygulanım olarak adlandırılmaktadır. Erkuş ve Günlü (2008) ise duyguların yaşanma sıklığı ve şiddetine göre etkilerinin farklı olabileceğini vurgulamaktadır. Duyguların yaşanma durumuna ilişkin olarak Cooper ve Sawaf (2010) duyguları çeşitli şiddet derecelerine ayırmaktadır. Aynı duyguyu farklı sıklıkta ve farklı şiddet düzeylerinde yaşamak mümkündür. Duygunun yaşanma sıklık ve şiddetindeki farklılığa bağlı olarak yol açabileceği farklı etkileri açıklamak üzere duygu durumu ifadesi kullanılmaktadır.

Duygu durumu, kişilerin duygusal kimliği hakkında bilgi sağlayabileceği gibi bir kurumda etkileşim halinde olanların ortak duygusal kimlikleri aracılığıyla beliren duygusal iklim ve duygusal kimlik hakkında da bilgi sağlar. Duygusal kimlik ve duygusal iklim hakkında bilgi edinebilmek için hangi duyguların hangi sıklıkta ve ne düzeyde yaşandığı belirlenmelidir (Akçay ve Çoruk, 2012). Duygusal kimlik bir kişiye, gruba, birime ya da kuruma uygulandığında duygu durumu açısından kişiler arasında, gruplar arasında, kurumlar arasında karşılaştırma yapma fırsatı sunar. Aynı zamanda bazı gruplarda belirli duygu durumlarının betimlenmesiyle örgütsel davranışın yönetimi bakımından temel oluşturur.

Duygular, deneyimlere bağlı olarak geliştiğinden sosyal ve kültürel boyut kapsamında bireyin yaşadığı ortama ilişkin bilgi sağlar. Örneğin bazı gruplar, toplumlar pozitif ve negatif duyguları daha düşük şiddette yaşarken; bazıları daha çok pozitif duyguları nispeten daha yüksek şiddette yaşamaktadırlar. Bir yerde coşkulu olma teşvik edilirken başka yerde durağan ve negatif duygular olumlu karşılanabilmektedir. Hofstede, Hofstede ve Minkov (2010) bireyin öne çıktığı kültürlerde coşkulu ve mutlu olmanın teşvik edildiğini fakat topluluğun öne çıktığ1 kültürlerde üzgün ve sakinliğin teşvik edildiğini açıklamaktadırlar. Övünç duymak farklı gruplarda farklı tepkiler alabilmektedir. Duygusal mesafe ve duygusal bağımlılık kültürel bir özellik olarak gruplar ve toplumlar arasında farklılaşmaktadır. Duygusal mesafe arttıkça kişiler duygularını ifade etmekten kaçınmaktadır. Duygusal bağlılığın yüksek olması, otoriter ve babacan kültürlerin bir özelliği olarak belirtilmektedir (Hofstede, Hofstede ve Minkov, 2010). Çalışanların yaşadıkları duyguların betimlenmesi, onların çalışma ortamlarına, yaptıkları işe ve mesleklerine ilişkin bilgi sağlar (Robbins ve Judge, 2015). Schein (2010), duygusal tepkileri örgütsel kültürün bir 
ögesi olarak inceler. Ona göre duygusal tepkiler de normlar tarafindan şekillenir. Bu normlar ise bir örgütte hâkim olan otoritenin, gücün ve etkinin kontrolünde olduğundan belirli bir örgütsel ortamda duygusal tepkilerin şekli örgütteki otoritenin niteliği hakkında fikir verir. Mesleklerin ve yapılan işlerin özellikleri, duygu durum bakımından meslekler arasında farklılıklara yol açabilir. İşlerin niteliği, çalışanların belirli duygu durumlarına sahip olmasını gerektirebilir. Bu doğrultuda öğretmenlerin sosyal ve duygusal yeterliliğinin önemini vurgulayan ve sosyal, duygusal ve eğitici olma yeteneklerini vurgulayan çeşitli araştırmalar bildirilmektedir (Nias, 1996). Öğretmen motivasyonu ve duygusal durumlarının, iyi öğrenci çıktılarıyla ilişkisi saptanmıştır (Jennings ve Greenberg, 2009). Örneğin öğretmenlik mesleğinde sabır, çocuk sevgisi, coşku, sorumluluk gibi duygular öne çıkmaktadır (Şişman, 2014). Eğitimcilerin sorumluluk sahibi olması ve duygusal bakımdan dengeli olması vurgulanmaktadır. Sorumluluk sahibi olanların motive olmaya eğilimli oldukları, duygusal dengeye sahip olanların da sakin, soğukkanlı, öz güvenli ve istikrarlı oldukları belirtilmektedir (Lunenburg ve Ornstein, 2013).

İhtiyaçlar, beklentiler, istekler karşılandığında mutluluk ve haz; karşılanmadığında ise hoşa gitmeyen bazen elem ve acı veren duygular yaşanmaktadır (Baloğlu, 2016). Kişinin sevdiği ve daha fazla istediği (neşe, sevgi, onur gibi) bir şey ile sevmediği ve kurtulmak istediği (hüzün, kin, suçluluk gibi) şeyler duygusal sınıflamanın temelini oluşturmaktadır (Akdoğan, 2016). Çok sayıda duyguya kaynaklık eden evrensel düzeyde ortak duygular mutluluk, şaşırma, korku, üzüntü, klzginlık ve iğrenme olarak sıralanmaktadır (Robbins ve Judge, 2015). Olumlu duygular hoşa giden deneyimlere bağlı olarak gelişirler (Ayçiçek, 2012). Her duygu farklı bir durumun işaretçisidir (Tarhan, 2006). Duygular mutluluk, neşe, iyimserlik gibi olumlu (pozitif); korku, kızgınlık, öfke, üzüntü gibi olumsuz (negatif) duygular olarak sinıflandırılabildiği gibi içe yönelen, dışa yönelen duygular ş̧eklinde de sınıflandırılabilmektedir. Kıskanma, imrenme gibi başkalarına yönelen duygular dışa yönelik; hayal kırıklığı gibi kaynă̆ dışarıdan olup içe yönelen duygular ise içe yönelik duygular biçiminde sinfflandırılabilmektedir (Akdoğan, 2016; Ayçiçek, 2012; Yaylacı, 2006). Bakioğlu (2014) öğretmenlerin duygularını bilişsel (ilgi, sıkıntı, merak vb.), bağlllık (sevgi, sempati, nefret vb.), bireysel (keyif, keder, öfke vb.), imgesel (utanç, suçluluk gibi kişinin kendi imajına yönelik) ve diğer imgelem (saygı, küçümseme gibi başkalarının bize karşı hissettiğini sandığımız) duygular şeklinde sınıflandırmaktadır. Kişilerin, grupların ya da kurumların duygu durumları betimlenerek yukarıda açıklanan sınıflandırmalar aracılığıyla onların ihtiyaç ve beklentilerinin karşılanma durumu hakkında bilgi oluşturulabilir. Sutton ve Wheatley (2003) olumlu duyguların olumsuz duygulara oranı kullanılarak mesleğe hazır oluş, mesleği sürdürme durumu hakkında önbilgi edinilebileceğini önermektedir. Halen görevde olan öğretmenler için duygusal anlamda çok iyi durumda olanların olumlu duygularının olumsuz duygularına oranı beş olarak belirtilmektedir. Bu oran mesleğin başında olanlarda daha düşük iken deneyim arttıkça oranın yükseldiği vurgulanmaktadır. Eğer bu oran bir ve altında ise meslekten ayrılma olasıllı̆ının yüksek olduğu değerlendirilmektedir.

Öğretmenlik mesleği çocukların ve gençlerin bedensel, zihinsel ve duygusal gelişimiyle doğrudan ilgilidir. Öğretmenlerin duygu durumları öğrenci gelişimi ve okulun işlevleri açısından oldukça önemlidir. Çocukların ve gençlerin duygusal bakımdan gelişmelerini sağlayacak olan öğretmenlerin pedagojik ve alan bilgi ve becerisi ile birlikte duygusal özellikleriyle de mesleği icra edebilecek durumda olmaları gerekir (Miller, 2012; Sezer, 2016). Eğitim örgütlerinde insan unsuru daha fazla ön plana çıktı̆̆ından duyguların yoğunluğu daha da fazla hissedilmektedir (Bakioğlu, 2014; Çoruk, 2012; Eren, 2001). Öğretmenler, öğrencileriyle, meslektaşlarıyla, okul yöneticileriyle sürekli etkileşim halindedir ve bu etkileşimlerinde çeşitli duygular yaşarlar. Yaşanan duygular okulun ve sınıfın duygusal iklimini oluşturur. Bir sınıfın ya da bir okulun duygusal kimliği onları diğerlerinden ayırıcı bir özelliktir. Negatif duyguları yaşayan ve bunları eylemlerine yansıtan öğretmenlerin öğrencilerin ve okulların çeşitli yönlerden gelişimini olumsuz etkiledikleri bildirilmektedir (Çalık, Tabak ve Yavuz Tabak, 2018; Demirtaş ve Küçük, 2016; Gasser, Grütter, Buholzer ve Wettstein, 2018; Schenke, Ruzek, Lam, Karabenick ve Eccles, 2018). Karmaşık iş-yaşam ilişkilerinin birbiriyle çelişen talepleri bireyleri engellenme korkusuna ve kaygıya sürükleyebilmektedir (Morgan, 2010). Sürekli korku ve endişe duyguları yaşayan kişiler olayları olumsuz olarak algılama eğilimindedirler. Bu açıdan öğretmenlerin duygusal sermayeleri okullardaki etkileşim ortamı aracılığıyla sürekli etki yaratan bir olgu şeklinde görülmektedir (Kervancı, 2008; Töremen ve Çankaya, 2008). Olumlu ilişkilerin temelinde öğretmenlerin pozitif duyguları bulunur (Demir, 2013). Evertson ve Emmer (2013)'e göre okulda ve sınıfta karşılıklı sevgi ve saygıya dayalı bir etkileşim öğretmenin duygusal yönden olgunluğunu gerektirir. Pozitif duyguların egemen olduğu örgütsel ortamlarda girişimciliğin, yaratıcıllğın, örgütsel öğrenmenin ve psikolojik güvencenin daha yüksek olduğu bildirilmektedir (Edmondson, Kramer ve Cook, 2004; Sutton ve Wheatley, 2003; Yıldırım ve Yenipınar, 2017). Öğretmenlerin duyguları, okuldaki performanslarını, öğrenci gelişimini ve okul iklimi dâhil birçok şeyi etkilediğinden onların hangi duyguları ne düzeyde ve hangi sıklıkta yaşadıkları betimlenmelidir. Bu betimleme, öğretmenliğe atanma öncesinde yapılabilirse mesleğe kabul sürecinde dikkate alınabilir. Öğretmenliğe atanma sürecinde veya öncesinde öğretmen adaylarını duygusal bakımdan tanımaya çalışmak ve onlara duygusal yönetim becerisi kazandırabilmek mesleğin işlevleri açısından önemlidir. Öğretmen adaylarının hangi duyguları hangi düzeyde ve hangi şiddette yaşadıkları betimlenebilirse, onları yetiştirme sürecinde önlemler alınabileceği gibi öğretmenliğe atanma sürecinde de bir değerlendirme başlı̆ı 
oluşturulmasına zemin hazırlayabilir. Duygular betimlenebilirse yönetilebilir. Yönetebilmek için öncelikle bilgi edinmek gereklidir.

Literatür taramasında, Türkiye'de öğretmenlik mesleği ve okul yönetimi çerçevesinde duygularla ilintili olarak örgütsel güven (Başaran, 2011; Çokluk Bökeoğlu ve Y1lmaz, 2008; Paker, 2009), sinizm (Kahveci ve Demirtaş, 2015; Kalağan ve Güzeller, 2010), iş doyumu, duygusal bağlllık ve duygusal tükenme (Babaoğlan, Altun ve Çakan, 2010; Cemaloğlu ve Şahin, 2007; Gök, 2016; Köse, 2016; Sarıdede, 2016), duygusal zekâ (Şahin, Aydoğdu ve Yoldaş, 2011) gibi konuların sıklıkla çalışılmasına karşın öğretmenlerin duygu durumlarını betimleyen ve inceleyen çok az çalışmaya erişilebilmiştir. Bu çalışmalardan biri Akdoğan (2016) tarafından okul yöneticilerinin duygu durumlarını betimlemek amacıyla yapılmıştır. Argon (2015) ise ilkokul öğretmenlerinin duygu durumlarının okul yöneticileri tarafından etkilenme durumunu görüşme yöntemiyle incelemiştir. Çalışma sayısındaki eksiklik Akçay ve Çoruk (2012) tarafından dile getirilerek; işgörenlerin duygu profillerinin, duygu tipolojilerinin betimlenmesinin örgütlerdeki duygusal iklimi yönetmede temel oluşturacağı vurgulanmaktadır. Uluslararası düzeyde de öğretmenlerin duygularını betimleyen az sayıda çalışmaya erişebilmiştir. Bu durumun temel sebeplerinden birinin duyguların öğretmenlik eğitiminde, mesleki uygulamalarda ve mesleki gelişimdeki öneminin ancak 2000'lere doğru fark edilmesi șeklinde belirtilmektedir. Özellikle farklı bağlam ve kültürlerde duygu durumlarını betimleyen çalışma ihtiyacı vurgulanmaktadır (Sutton ve Wheatley, 2003). Yurtdışındaki araştırmalarda bu çalışmanın odağına en yakın olan öğretmenlerin kaygıları (Kyriacou, 2001), duygusal destek (Gasser vd., 2018; Schenke vd., 2018), sınıf değişkenleriyle öğretmenlerin duygusal yeterlikleri arasındaki ilişki (Jennings ve Greenberg, 2009) üzerine gerçekleştirilen çalışmalara erișilmiştir. En ilgili çalışmalar Nias (1996) tarafından öğretim sırasında yaşanılan duygular ve Zembylas, (2003) tarafından öğretmenlerin performans ve duygu algısı üzerinedir. Zembylas (2003) ise kuramsal çalışmasında öğretmenlerin duygularının onların kimlik oluşturmalarının temelini oluşturduğunu ve güç ilişkileriyle şekillendiği sonucuna ulaşmıştır. Skaalvik ve Skaalvik (2009) tarafından teyit edilerek öğretmenlerdeki duygusal bakımdan körelmenin ebeveynlerle olan ilişki kalitesini etkileyebildiği saptanmıştır. İngiltere'de farklı kademelerdeki okullarda görevli 257 öğretmen üzerine gerçekleştirilen çalışmada ise öğretmenlerin beşte birinin stres düzeyinin yüksek düzeyde olduğu ve stres kaynaklarının başında öğrencilerin davranışları, çalışma koşulları ve zaman baskısı olduğu belirlenmiştir (Kyriacou ve Sutcliffe, 1978). Ayrıca öğretmenlerin duygularının öğrencilere transfer edilebildiği saptanmıştır (Frenzel, Becker-Kurz, Pekrun, Goetz ve Lüdtke, 2017). Öğretmenlik mesleğini gelecekte icra edecek öğretmen adaylarının duygusal bakımdan tanınması, mesleğin işlevi açısından önemli görülmektedir. Ulusal ve uluslararası düzeyde öğretmen adaylarını duygu durumları bakımından betimleyen araştırma eksikliği dikkate alınarak bu araştırmada öğretmen adaylarının duygu durumlarının betimlenmesi amaçlanmıştır. Bu temel amaca hizmet edecek şekilde öğretmen adaylarının $i$ ) olumlu ve olumsuz duygu durumlarını, ii) içe yönelen ve dışa yönelen duygu durumlarını, iii) bilişsel-bağlılık-bireysel-imgesel-diğer imgelem duyguları ve $i v$ ) öğretmenlik mesleğine duygusal bakımdan hazır oluş durumunu saptamak alt amaçları belirlenmiştir.

\section{YÖNTEM}

\subsection{Araştırmanın modeli}

Sutton ve Wheatley (2003) duygu durumu üzerine yapılan çalışmalarda deney, görüşme, gözlem, örnek olay, video kaydı, arşiv inceleme, günlük tutma, metafor kullanma ve tarama gibi çeşitli modeller kullanıldığını açıklamaktadırlar. Öğretmen adaylarının duyguyu yaşama şiddeti ile sıklığından yola çıkarak duygu durumlarını ortaya koymayı amaçlayan bu çalışma tarama modelinde betimsel bir araştırmadır. Tarama modeli, bir durumu var olduğu şekilde betimlemeyi amaçlar (Karasar, 2008).

\section{2. Çalışma Grubu}

Araştırmanın çalışma grubu, 2017-2018 Bahar yarıyılında Aksaray Üniversitesi Eğitim Fakültesinde lisans ve pedagojik formasyon programlarında kayıtlı öğretmen adaylarından oluşmuştur. Örnekleme, basit seçkisiz yöntemle erişilmiştir. Öğretmen adaylarından çalışmaya katılmak isteyenler ayrım gözetilmeksizin eşit seçilme şansıyla örneklemde yer almışlardır (Fraenkel, Wallen ve Hyun, 2012). Örneklemde kadınlar \% 71 ile temsil edilmiştir. Program türüne göre en büyük grup fen bilimleri (yaklaşık \% 40) ağırlıklı grup iken en az sanat ağırlıklı (\% 9) gruptur. Dil ağırlıklı programdaki öğrenciler toplam içinde yaklaşık \% $32 \mathrm{iken;} \mathrm{dini} \mathrm{bilgiler} \mathrm{ağırlıklı} \mathrm{grup} \mathrm{\%}$ 19'luk orana sahiptir.

Öğretmen yetiştirmede $\operatorname{ard} \iota_{\text {şı }}$ (teorik eğitimin bitimini takip eden staj eğitimi) ve eşzamanlı (teorik ve staj eğitimi birlikte) olmak üzere farklı program yöntemleri bulunmaktadır (Abazoğlu, 2014). Tablo 1'e göre katılımcıların neredeyse yarısı ardışık program yöntemine göre yetiştirilirken diğer yarısı eşzamanlı program yöntemi içinde yetiştirilmektedir. 


\begin{tabular}{llrrr}
\hline Tablo 1. & & & \\
Katılımcların Demografik Özellikleri & & & \\
\hline Özellikler & & $f$ & $\%$ \\
\hline \multirow{2}{*}{ Cinsiyet } & Kadın & 495 & 71.2 \\
& Erkek & 200 & 28.8 \\
& Toplam & 695 & 100.0 \\
\hline \multirow{4}{*}{ Program } & Dil ve sosyal ağı̆lıklı (Türkçe, İngilizce, Tarih, Turizm...) & 221 & 31.7 \\
& Fen bilimleri ağıllıklı (Fen, matematik, sağlık, psikolojik danışma...) & 277 & 39.8 \\
& Sanat ağırlıklı (Resim ve müzik eğitimi) & 63 & 09.0 \\
& Dini bilgiler ağırlıklı (İslami İlimler) & 134 & 19.2 \\
& Toplam & 695 & 100.0 \\
Öğretmen & Ardışık & 345 & 49.6 \\
yetiştirme & Eşzamanlı & 350 & 50.4 \\
biçimi & Toplam & 695 & 100.0 \\
\hline
\end{tabular}

\subsection{Veri toplama aracı}

Bu çalışmada iki bölümden oluşan duygu durum ölçeği kullanılmıştır. Ölçeğin birinci bölümü demografik bilgileri içermekte iken ikinci bölümü ise katılımcıların duygu durumlarını ölçmeye yöneliktir. Araştırma kapsamında kullanılan duygu durumları ölçeğinin orijinal hali Akdoğan (2016) tarafindan okul yöneticileri üzerinde geliştirilmiştir. Fakat söz konusu çalışmada faktör analizleri ve madde analizleri yapılmamıştır. Mevcut çalışmada ise araştırmacılar söz konusu ölçme aracını öğretmen adayları üzerinde uygulayarak faktör ve madde analizlerini yapmışlardır. Ölçek, 54 farklı duygunun yaşanma sıklığı ve yaşanma şiddetini saptamaya yöneliktir. Duygunun yaşanma sıklığını belirlemek için beşli Likert (1: Hiç - 5: Sürekli); duygunun yaşanma şiddeti ise üçlü Likert (1: Düşük, 2: Orta, 3: Yüksek) ile derecelendirilmiştir. Duygu durumu ise duygunun yaşanma sıklığı ve şiddetini içerdiğinden veriler dönüştürülerek (duygu durumu=duygunun yaşanma sıklı̆̆ x duygunun yaşanma şiddeti) hesaplanmıştır. Hesaplanan duygu durumu puanları beşli Likert ölçeğinde dönüştürülmüştür (1: Neredeyse hiç 5: Fazlasıyla). Faktör analizleri ve madde analizleri duygu durumu puanları üzerinden gerçekleştirilmiştir.

Toplam 732 katılımcıdan elde edilen veriler üzerinden veri ayıklanması sonucunda 695 katılımcının verisi esas alınarak (i) madde ayırt ediciliği, (ii) yapı geçerliği, (iii) güvenirlik analizleri gerçekleştirilmiştir. Kayıp veriler, seri ortalamaları ile değiştirilmiş̧tir. Dağılımın normalliği kontrol edilmiş ve uç değerler z-puanlarıyla incelenerek, |3.29|'dan büyük olan veriler analizden çıkarılmıştır (Tabachnick ve Fidell, 2007).

Ölçme aracının madde-toplam madde ilişki değerleri Pearson çarpım momentler korelasyon analiziyle hesaplanmıştır. Ölçme aracının yapı geçerliğini test etmek için aynı veriler üzerinde açımlayıcı faktör analizi (AFA) ve doğrulayıcı faktör analizi (DFA) yapılmıştır. Ölçeğin iç güvenirlik düzeyi ve maddelerin ayrışıklığı Cronbach's Alpha $(a)$ iç tutarlılık katsayısı ile hesaplanmıştır. Bu çerçevede öğretmen adaylarının duygu durumları olumlu-olumsuz, içe yönelen-dışa yönelen, bilişsel-bağlllık-bireysel-imgesel-diğer imgeleme sınıflamaları ile analiz edilmiştir. Bu analizlerde her bir sınıflama için indeks puanları hesaplanmıştır. İndeks puanlarına temel oluşturan sınıflamalar hem istatistiksel (AFA, DFA) hem de uzman görüşleriyle saptanmıştır. Ayrıca olumlu duyguların olumsuz duygulara oranı incelenmiştir. Bu bağlamda öğretmen adaylarının duygu durumları yüzde $(\%)$, frekans $(f)$, aritmetik ortalama $(\bar{x})$ ve standart sapma (S) skorları ile betimlenmiştir. Sürekli veriler yorumlanırken 1.00-1.79 arası neredeyse hiç yaşanmamakta; 1.80-2.59 arası çok az yaşanmakta;2.60-3.39 arası bir ölçüde yaşanmakta; 3.40-4.19 arası oldukça yaşanmakta ve 4.20-5.00 arası fazlasıyla yaşanmakta şeklinde yorumlanmıştır.

Madde-toplam korelasyonlarında elde edilen korelasyon katsayıları .33 ile .58 arasında olduğundan tüm maddeler analize alınmıştır. Yapı geçerliliği için Varimax döndürme ile temel eksen faktör analizi kullanılarak açımlayıcı faktör analizi yapılmıştır. Faktör yükleri |.40|'ın altında olan veya faktör yükü en az iki faktör için |.40|'ın üstünde olan maddeler faktörlere atanmadı. İlk olarak toplanan verilerin $K M O=.95$ ve Barlett $(p<.01)$ test analizleri sonuçlarıyla açımlayıcı faktör analizinin yapılabileceği anlaşılmış̧ır. Faktör analizine alınan toplam 54 maddeden yalnızca 19'u toplam varyansın \% 45'ini açılayan öz değeri 1'den büyük iki (2) faktörlü bir yapı üretmiştir. Maddelerin faktör yükleri ise |.49| ile |.76| arasında değişmektedir (Ek).

Ölçek faktörlerinin Cronbach's Alpha $(\alpha)$ iç tutarlılık katsayısı .80 ile .85 arasında saptanmıştır. Ölçme aracı geneli için $\alpha$ iç tutarlılık katsayısı .82 olarak hesaplanmıştır. Bu değerlere göre, ölçeğin yüksek düzeyde güvenilir olduğu söylenebilir (Seçer, 2015). Ölçek genel olarak olumlu ve olumsuz duygu durumlarını ölçtüğü için ilişkinin birbirinin tersi yönde olması gerekmektedir. Bu nedenle ölçeğin faktörleri arasında negatif düzeyde ilişki beklenilmektedir. Çalışmada faktörler arasında ayrım geçerliği incelendiğinde, faktörleri arasındaki korelasyon katsayıları -.61 olarak saptanmıştır. 
Doğrulayıcı faktör analiziyle bir önceki aşamada saptanan faktör yapısı test edilmiştir. Doğrulayıcı faktör analizi LISREL 8.7 (Jöreskog ve Sörbom, 1996) (moment matrix, kovaryans, normal skor) ile gerçekleştirilmiştir. Şekil 1 'de doğrulayıcı faktör analizi sonucu görülmektedir. Uyum indeks değerleri incelendiğinde $\chi^{2}=373.44$, sd=151 ve $\chi^{2} / \mathrm{sd}=2.47$ olduğundan model ile veri seti arasında uyum olduğunu göstermektedir. $\mathrm{RMSEA}=0.05$ olduğundan uyumun geçerliği desteklenmektedir. Diğer indeks değerleri incelendiğinde ise NNFI=0.96, CFI=0.93, GFI=0.89, $\mathrm{AGFI}=0.86$ olarak hesaplanmış ve referans uyum indeks değerleriyle karşılaştırıldığında ölçeğin faktör yapısının doğrulandığı görülmektedir.

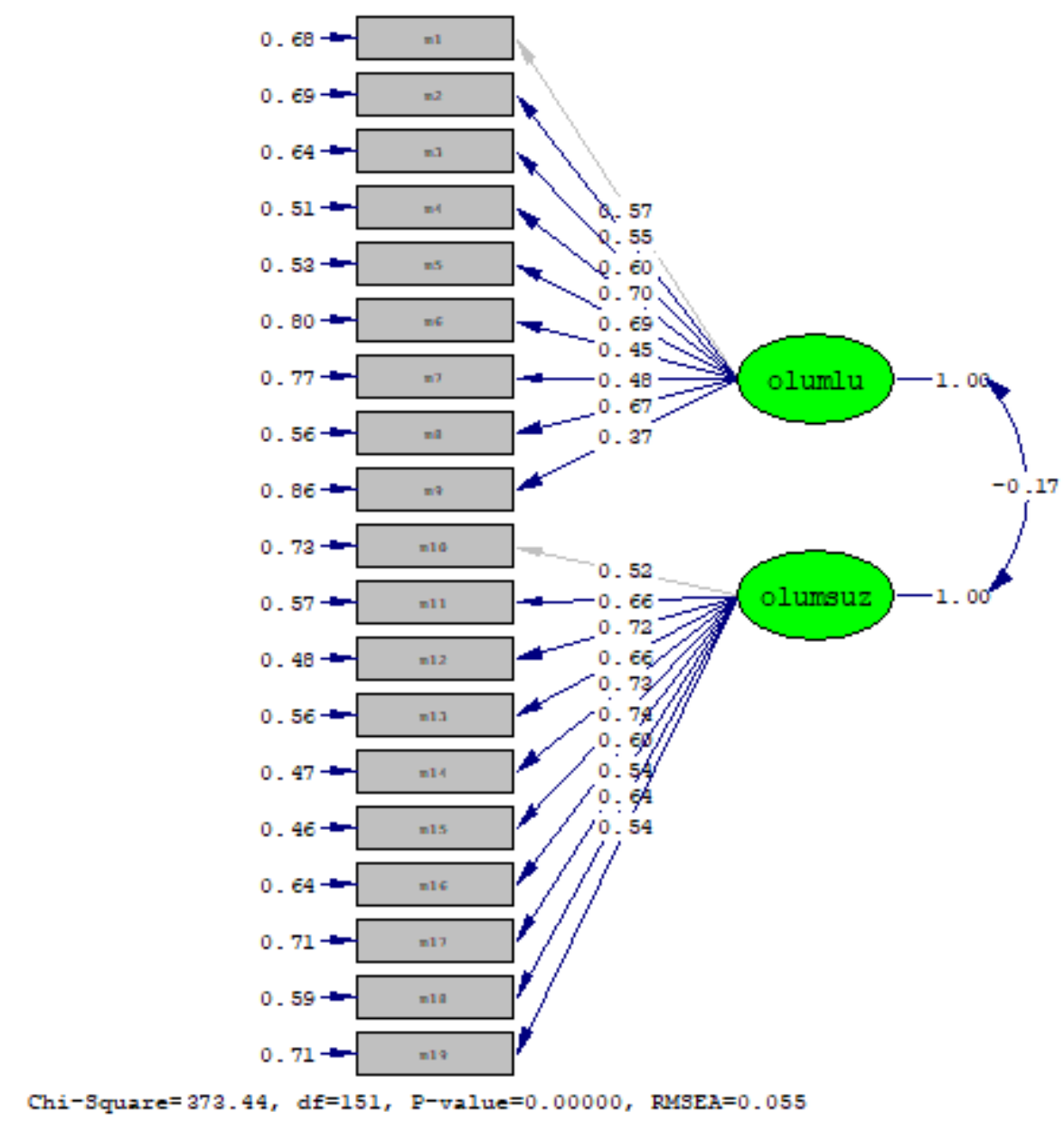

Şekil 1. Ölçeğe ait doğrulayıcı faktör analizi yol diyagramı

\subsection{Veri toplama süreci ve analizi}

Ölçme araçları, gerekli izinlerin alınmasının ardından, 2017-2018 akademik yılının Mart-Nisan ayları arasındaki dönemde uygulanmıştır. Katılımcıların toplu halde bulundukları gerçek ortamlarda, dersliklerde uygulanmıştır. Araştırmacılar tarafından ön bilgi verilerek gönüllü olanlara anket formları dağıtılmış ve doldurulma işlemi ardından tekrar toplanmıştır. Ölçeğin doldurulma işlemi yaklaşık 20-25 dakika sürmüştür. Formlardaki veriler bilgisayar ortamına aktarılmadan önce, norm dışı formlar (işaretlenmemiş, yarıdan fazlası boş bırakılmış veya aynı seçeneklerin işaretlenmiş olduğu formlar) analiz dışı bırakılmıştır. Veriler SPSS 22 istatistik paket programına girildikten sonra verilerin analize uygunluğu incelenmiştir. Bu süreçteki incelemede kayıp, yineleme ve uç değer analizleri yapılmıştır. Bu doğrultuda 732 katılımcıdan elde edilen veriler üzerinden veri ayıklanması sonucunda 695 katılımcının verisi esas alınarak analize tabi tutulmuştur. Araştırmanın amacı kapsamında olumlu ve olumsuz, içe yönelen ve dışa yönelen, bilişsel-bağl1lık-bireysel-imgesel-diğer imgelem duyguları ve öğretmenlik mesleğine duygusal bakımdan hazır oluş durumunu belirlemek amacıyla tanımlayıcı istatistiklerden ortalama $(\bar{x})$, standart sapma (S), frekans $(f)$ ve yüzde (\%) analiz teknikleri kullanılmıştır. 


\section{BULGULAR}

Öğretmen adaylarının duygu durumları alt amaçlara göre betimlenmiştir. Bu kapsamda sırasıyla öğretmen adaylarının olumlu-olumsuz duygu durumu, içe-dışa yönelik duygu durumu, bilişsel-bağlılık-bireysel-imgesel ve diğer imgelem duygu durumu ortaya konulmuştur. Son aşamada onların mesleğe duygusal bakımdan hazır oluşlarının bir göstergesi olarak olumlu duyguların/olumsuz duygulara oranı hesaplanmıştır.

Tablo 2, öğretmen adaylarının olumlu ve olumsuz duygu durumlarını betimleyici istatistikler yardımıyla göstermektedir. Frekans değerleri duyguların çok az ya da neredeyse hiç düzeylerinde yaşandığına işaret etmektedir. Frekans değerleri diğerlerine göre daha yüksek olan merhamet ve can sıkıntısı katılımcıların diğer duygulara göre daha yoğun yaşadıkları duygular olarak belirmektedir. Aritmetik ortalama ve standart sapma değerlerine göre öğretmen adayları olumlu ya da olumsuz duyguları çok az yoğunlukta yaşamaktadırlar. Olumsuz duyguların yaşanma düzeyine $(\bar{x}=2.16, \mathrm{~S}=1.19)$ göre öğretmen adayları olumlu duyguları daha yoğun yaşamaktadırlar $(\bar{x}=2.57, \mathrm{~S}=1.18)$. Yüzde dağılımlarına göre öğretmen adaylarının büyük çoğunluğu (\% 71.8) çok az ya da hiç olumsuz duygu yaşamadığını belirtirken yalnızca yaklaşık \% 15'i olumsuz duyguları oldukça ve fazlasıyla yaşamaktadır. Olumlu duyguların yaşanması bakımından katılımcıların \% 55'i çok az ya da hiç olumlu duygu yaşamadığını belirtmektedir. Olumlu duyguları oldukça veya fazlasılyla yaşayanların oranı ise \% 22.7 'dir. $\mathrm{Bu}$ dağılıma göre öğretmen adaylarının duygusal bakımdan canlılıktan uzak, durgunluk ve duygusal yoksunluk yaşadığı veya duygu yaşama fakirliği içinde olduğu söylenebilir. Bu yorumu destekler şekilde katılımcıların \% 64.6'sı hiç ya da çok az coşku yaşadığını belirtmektedir. Likert derecelemesinde duygu durumunun bir ölçüde yaşandığını belirten aralıkta $(2.60 \leq \bar{x} \leq 3.39)$ yalnızca dört duygu (cesaretlenme, merhamet, sevgi, can sıkıntısı) yer almaktadır. Diğerleri neredeyse hiç yaşanmamakta ya da çok az yaşanmaktadır.

\section{Tablo 2.}

Ögretmen Adaylarının Olumlu ve Olumsuz Duygu Durumu Dă̆llımları

\begin{tabular}{|c|c|c|c|c|c|c|c|c|c|c|c|c|c|}
\hline \multirow{2}{*}{ 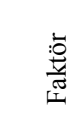 } & \multirow{2}{*}{ Duygular } & \multirow[b]{2}{*}{$\bar{x}$} & \multirow[b]{2}{*}{$\mathbf{S}$} & \multicolumn{2}{|c|}{ Neredeyse Hiç } & \multicolumn{2}{|c|}{ Çok az } & \multicolumn{2}{|c|}{ Bir ölçüde } & \multicolumn{2}{|c|}{ Oldukça } & \multicolumn{2}{|c|}{ Fazlasıyla } \\
\hline & & & & $f$ & $\%$ & $f$ & $\%$ & $f$ & $\%$ & $f$ & $\%$ & $f$ & $-\%$ \\
\hline \multirow{9}{*}{ 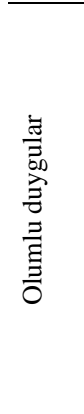 } & Gurur duyma & 2.58 & 1.13 & 108 & 15.5 & 277 & 39.9 & 163 & 23.5 & 96 & 13.8 & 51 & 7.3 \\
\hline & Zesaretlenme & 2.61 & 1.18 & 118 & 17.0 & 260 & 37.4 & 153 & 22.0 & 104 & 15.0 & 60 & 8.6 \\
\hline & zoşku duyma & 2.35 & 1.12 & 158 & 22.7 & 291 & 41.9 & 134 & 19.3 & 69 & 9.9 & 43 & 6.2 \\
\hline & Hoşnut olma & 2.48 & 1.06 & 126 & 18.1 & 258 & 37.1 & 188 & 27.1 & 96 & 13.8 & 27 & 3.9 \\
\hline & Huzur hissetme & 2.46 & 1.14 & 151 & 21.7 & 244 & 35.1 & 168 & 24.2 & 93 & 13.4 & 39 & 5.6 \\
\hline & Merhamet hissetme & 2.99 & 1.34 & 105 & 15.1 & 186 & 26.8 & 135 & 19.4 & 146 & 21.0 & 123 & 17.7 \\
\hline & Minnet duyma & 2.28 & 1.19 & 198 & 28.5 & 275 & 39.6 & 98 & 14.1 & 74 & 10.6 & 50 & 7.2 \\
\hline & jevgi hissetme & 2.81 & 1.27 & 119 & 17.1 & 194 & 27.9 & 174 & 25.0 & 118 & 17.0 & 90 & 12.9 \\
\hline & Jmutlanma & 2.53 & 1.20 & 142 & 20.4 & 249 & 35.8 & 165 & 23.7 & 72 & 10.4 & 67 & 9.6 \\
\hline \multicolumn{2}{|c|}{ Jrtalama } & 2.57 & 1.18 & 136 & 19.6 & 248 & 35.7 & 153 & 22.03 & 96 & 13.9 & 61 & 8.8 \\
\hline \multirow{10}{*}{ 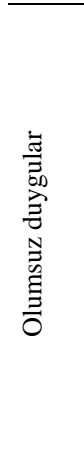 } & Zan s1kıntıs1 & 2.79 & 1.34 & 133 & 19.1 & 205 & 29.5 & 131 & 18.8 & 124 & 17.8 & 102 & 14.7 \\
\hline & Saresizlik hissetme & 2.02 & 1.18 & 290 & 41.7 & 241 & 34.7 & 63 & 9.1 & 60 & 8.6 & 41 & 5.9 \\
\hline & Jayal kırıklığ & 2.31 & 1.22 & 196 & 28.2 & 277 & 39.9 & 94 & 13.5 & 70 & 10.1 & 58 & 8.3 \\
\hline & Kaygilanma & 2.46 & 1.25 & 177 & 25.5 & 239 & 34.4 & 122 & 17.6 & 94 & 13.5 & 63 & 9.1 \\
\hline & Sederlenme & 2.09 & 1.23 & 281 & 40.4 & 232 & 33.4 & 78 & 11.2 & 48 & 6.9 & 56 & 8.1 \\
\hline & Mutsuz olma & 2.11 & 1.17 & 245 & 35.3 & 275 & 39.6 & 78 & 11.2 & 49 & 7.1 & 48 & 6.9 \\
\hline & Vefret hissetme & 1.81 & 1.10 & 359 & 51.7 & 217 & 31.2 & 45 & 6.5 & 40 & 5.8 & 34 & 4.9 \\
\hline & J̈fkelenme & 2.08 & 1.13 & 250 & 36.0 & 275 & 39.6 & 72 & 10.4 & 62 & 8.9 & 36 & 5.2 \\
\hline & Jmidini yitirme & 1.89 & 1.08 & 313 & 45.0 & 252 & 36.3 & 61 & 8.8 & 34 & 4.9 & 35 & 5.0 \\
\hline & Yalnızlık hissetme & 2.03 & 1.16 & 274 & 39.4 & 263 & 37.8 & 66 & 9.5 & 47 & 6.8 & 45 & 6.5 \\
\hline \multicolumn{2}{|c|}{ Jrtalama } & 2.16 & 1.19 & 252 & 36.2 & 248 & 35.6 & 81 & 11.7 & 63 & 9.0 & 52 & 7.5 \\
\hline
\end{tabular}

Öğretmen adaylarının en yoğun yaşadığı duygular sırasıyla merhamet $(\bar{x}=2.99, \mathrm{~S}=1.34)$, sevgi $(\bar{x}=2.81, \mathrm{~S}=1.27)$, can sıkıntısı $(\bar{x}=2.79, \mathrm{~S}=1.34)$ ve cesarettir $(\bar{x}=2.61, \mathrm{~S}=1.18)$. Merhamet sözcüğü "Bir kimsenin veya bir başka canlının karşılaştığı kötü durumdan dolayı duyulan üzüntü, acıma” olarak açıklanmaktadır (http://www.tdk.gov.tr). Öğretmen adaylarının yaşadıkları çevrede ya da televizyonda, internette, sosyal medyada kötü durumda kalan bir kimse ya da canlıya sıklıkla tanık oldukları söylenebilir. Sevgi, bir şeye ya da bir kişiye yakın ilgi ve bağlılık olarak tanımlanabilir. Öğretmen adaylarının diğer duygulara göre en yoğun yaşadıkları bu 
duygu, merhamet duygusu gibi başkalarına yöneliktir. Bu açıdan öğretmen adaylarında en yoğun duyguların kaynağında başkaları bulunduğundan onların etken değil edilgen konumda oldukları öne sürülebilir. Bu yorumu destekler şekilde öğretmen adaylarının yoğun olarak yaşadığı bir başka duygu can sıkıntısıdır. Can sıkıntısı, yapacak bir şey bulamamaktan dolayı yaşanan bir duygudur. Eylemsizlik haline işaret ettiği gibi hedefsizlik durumuna da işaret edebilir. Öğretmen adaylarının, araştırmanın gerçekleştirildiği dönemin sınav dönemi olmayışından kaynaklı duygusal bir durgunluk düşünülmekle birlikte istekleriyle bu isteklerini gerçekleştirebilecekleri şartlar arasındaki uyumsuzluğu da hatırlatmaktadır. Katılımcıların, beklentilerini karşılayabileceği uygun şartlara sahip olmadıkları ileri sürülebilir. Katılımcıların duygu durumları, içe yönelen ve dışa yönelen duygular bakımından incelenmiş ve dağılımlar Tablo 3’te gösterilmiştir. Öğretmen adaylarının içe yönelen olumlu duyguları gurur duyma, cesaretlenme, coşku duyma, hoşnut olma, huzur hissetme ve umutlanma duygularını içermektedir. Içe yönelen olumsuz duyguları ise can sıkıntısı, çaresizlik, kaygılanma, kederlenme, mutsuz olma, ümidini yitirme ve yalnızlık hissetme duygularını kapsamaktadır. Tablo 3'e göre ögretmen adayları içe yönelen olumlu duyguları $(\bar{x}=2.41, \mathrm{~S}=.94)$, içe yönelen olumsuz duygulara $(\bar{x}=2.05, \mathrm{~S}=1.04)$ göre daha fazla yaşamaktadırlar.

\section{Tablo 3.}

Öğretmen Adaylarının İçe Yönelen ve Dışa Yönelen Duygu Durumu Dağılımları

\begin{tabular}{|c|c|c|c|c|c|c|c|c|c|c|c|c|c|}
\hline \multirow[t]{2}{*}{ Duygular } & & \multirow[b]{2}{*}{$\bar{x}$} & \multirow[b]{2}{*}{$\mathbf{S}$} & \multicolumn{2}{|c|}{ Neredeyse Hiç } & \multicolumn{2}{|c|}{ Çok az } & \multicolumn{2}{|c|}{ Bir ölçüde } & \multicolumn{2}{|c|}{ Oldukça } & \multicolumn{2}{|c|}{ Fazlasıyla } \\
\hline & & & & $f$ & $-\%$ & $f$ & $-\%$ & $f$ & $-\%$ & $f$ & $-\%$ & $f$ & $-\%$ \\
\hline İçe & Olumlu & 2.41 & .94 & 106 & 15.3 & 300 & 43.2 & 204 & 29.4 & 70 & 10.1 & 15 & 2.2 \\
\hline Yönelen & Olumsuz & 2.05 & 1.04 & 253 & 36.4 & 253 & 36.4 & 107 & 15.4 & 67 & 9.6 & 15 & 2.2 \\
\hline Toplam & Genel içe yönelen & 2.19 & .71 & 98 & 14.1 & 385 & 55.4 & 193 & 27.8 & 18 & 2.6 & 1 & .1 \\
\hline \multirow{2}{*}{$\begin{array}{c}\text { Dişa } \\
\text { Yönelen }\end{array}$} & Olumlu & 2.66 & 1.21 & 149 & 21.4 & 159 & 22.9 & 226 & 32.5 & 101 & 14.5 & 60 & 8.6 \\
\hline & Olumsuz & 1.91 & 1.05 & 318 & 45.8 & 200 & 28.8 & 123 & 17.7 & 30 & 4.3 & 24 & 3.5 \\
\hline Toplam & Genel dişa yönelen & 2.25 & .86 & 137 & 19.7 & 297 & 42.7 & 215 & 30.9 & 43 & 6.2 & 3 & .4 \\
\hline
\end{tabular}

Öğretmen adaylarının dışa yönelen olumlu duyguları merhamet hissetme, minnet duyma ve sevgi hissetme duygularını içerirken dışa yönelen olumsuz duyguları hayal kırıklığı, nefret hissetme ve öfkelenme duygularını kapsamaktadır. Dışa yönelen olumlu duyguları $(\bar{x}=2.66, \mathrm{~S}=1.21)$, dişa yönelen olumsuz duygularından $(\bar{x}=1.91$, $\mathrm{S}=1.05)$ daha yoğun yaşadıkları belirtilebilir. İçe yönelen $(\bar{x}=2.19, \mathrm{~S}=.71)$ ve dişa yönelen $(\bar{x}=2.25, \mathrm{~S}=.86)$ duyguların genel dağılımı açısından öğretmen adaylarının dişa yönelik duyguları daha yoğun yaşadıkları anlaşılmaktadır. Bir başka söyleyişle öğretmen adaylarının kendi içsel duygularını daha düşük yoğunluklu yaşarken başka kişi, grup ya da nesneye yönelik duyguları daha yüksek yoğunluklu yaşadıkları belirtilebilir.

Tablo 4.

Öğretmen Adaylarının Bilişsel-Bă̆lılık-Bireysel-İmgesel ve Dĭger İmgelem Duygu Durumu

\begin{tabular}{|c|c|c|c|c|c|c|c|c|c|c|c|c|}
\hline \multirow[t]{2}{*}{ Duygular } & \multirow[b]{2}{*}{$\bar{x}$} & \multirow[b]{2}{*}{$\mathbf{S}$} & \multicolumn{2}{|c|}{ Neredeyse Hiç } & \multicolumn{2}{|c|}{ Çok az } & \multicolumn{2}{|c|}{ Bir ölçüde } & \multicolumn{2}{|c|}{ Oldukça } & \multicolumn{2}{|c|}{ Fazlasıyla } \\
\hline & & & $f$ & $\%$ & $f$ & $\%$ & $f$ & $\%$ & $f$ & $\%$ & $f$ & $\%$ \\
\hline Bilişsel & 2.21 & .87 & 226 & 32.5 & 299 & 43.0 & 102 & 14.7 & 51 & 7.3 & 17 & 2.4 \\
\hline Bağlılık & 2.54 & .79 & 150 & 21.6 & 193 & 27.8 & 261 & 37.6 & 83 & 11.9 & 8 & 1.2 \\
\hline Bireysel & 2.34 & .56 & 125 & 18.0 & 333 & 47.9 & 214 & 30.8 & 23 & 3.3 & - & - \\
\hline İmgesel & 2.40 & .65 & 146 & 21.0 & 316 & 45.5 & 183 & 26.3 & 44 & 6.3 & 6 & .9 \\
\hline Diğer İmgelem & 2.15 & .85 & 250 & 36.0 & 267 & 38.4 & 112 & 16.1 & 52 & 7.5 & 14 & 2.0 \\
\hline
\end{tabular}

Öğretmen adaylarının duyguları bilişsel, bağlılık, bireysel, imgesel ve diğer imgelem duyguları şeklinde sınıflandırılmıştır. Bu sınıflandırmaya bağlı hesaplanan betimsel istatistiklere göre öğretmen adayları duyguları çok az yoğunlukta yaşamaktadırlar. Fakat sınıflandırma gruplarının kendi içinde en yoğunlukla bağlılık duygularını (merhamet, sevgi, nefret) yaşarken $(\bar{x}=2.54, \mathrm{~S}=.79)$; en düşük yoğunlukta diğerlerinin kendisi hakkında hissettiğini düşündüğü-diğer imgelem (minnet, çaresizlik)- duyguları yaşamaktadır $(\bar{x}=2.15, \mathrm{~S}=.85)$. Bilişsel duyguları (umutlanma, ümidini yitirme) çok az yoğunlukta $(\bar{x}=2.21, \mathrm{~S}=.87$ ) yaşayan öğretmen adayları aynı kategoride (çok az) yer alan fakat ortalama açısından biraz daha yoğun olarak bireysel duyguları (coşku, hoşnut olma, huzur, can sıkıntısı, kaygı, keder, öfke, yalnızlık) $(\bar{x}=2.34, \mathrm{~S}=.56)$ ve imgesel duyguları (gurur, cesaret, mutsuzluk, hayal kırıklığı $)(\bar{x}=2.40, \mathrm{~S}=.65)$ yaşamaktadırlar. 
Öğretmen adaylarının duygusal açıdan mesleğe hazır oluşlarına ilişkin Sutton ve Wheatley (2003) tarafından önerilen gösterge olumlu duyguların olumsuz duygulara oranıyla hesaplanmaktadır. Bu çalışmada öğretmen adaylarının olumlu duygularının ortalamas $\bar{x}=2.57(\mathrm{~S}=1.18)$ iken olumsuz duygularının ortalaması $\bar{x}=2.16$ $(\mathrm{S}=1.19)$ dır. $\mathrm{Bu}$ iki değerin oranlanması sonucunda 1.19 değeri hesaplanmıștır. Bu kapsamda öğretmen adaylarının duygusal bakımdan mesleğe hazır oluşlarını gösteren indeksin minimum puanı .21 iken maksimum puan 4.56'dır. Tablo 5, öğretmen adaylarının öğretmenlik mesleğine duygusal bakımdan hazır olma durumuna ilişkin dağılımlarını göstermektedir. Dağılıma göre katılımcıların büyük çoğunluğunun (\% 84.4) duygusal bakımdan hiç ya da çok az düzeyde öğretmenlik mesleğine hazır olduğu anlaşılmaktadır. Duygusal bakımdan öğretmenlik mesleğine oldukça ve tamamen hazır olanların oranı yalnızca \% 3.4’tür.

\section{Tablo 5.}

Ögretmen Adaylarının Ögretmenlik Mesleğine Duygusal Hazır Olma Bakımından Dă̆llımları

\begin{tabular}{|c|c|c|c|c|c|c|c|c|c|c|c|c|}
\hline \multirow[t]{2}{*}{ Likert Dereceleri } & \multicolumn{2}{|c|}{ Neredeyse Hiç } & \multicolumn{2}{|c|}{ Çok az } & \multicolumn{2}{|c|}{ Bir ölçüde } & \multicolumn{2}{|c|}{ Oldukça } & \multicolumn{2}{|c|}{ Tamamen } & \multicolumn{2}{|c|}{ Toplam } \\
\hline & $f$ & $\%$ & $f$ & $\%$ & $f$ & $\%$ & $f$ & $\%$ & $f$ & $\%$ & $f$ & $\%$ \\
\hline Dağılım & 276 & 39.7 & 311 & 44.7 & 84 & 12.1 & 19 & 2.7 & 5 & 0.7 & 695 & 100.0 \\
\hline
\end{tabular}

Görevde olup duygusal anlamda çok iyi durumda olan öğretmenler için söz konusu oranın 5.00 hesaplanmas1 beklenmektedir. Mesleğin başında bu değerin düşük olacağı fakat deneyimle birlikte yükseleceği ifade edilmektedir (Sutton ve Wheatley, 2003). Bu referans dikkate alındığında, mevcut çalışmada öğretmen adayları için hesaplanan duygusal bakımdan mesleğe hazır oluş ortalama puanı ve Tablo 5'te gösterilen dağılıma göre öğretmen adaylarının duygusal bakımdan henüz mesleğe hazır olmadıkları söylenebilir.

\section{TARTIŞMA, SONUÇ ve ÖNERILER}

Tarama yöntemiyle nicel veri analiz teknikleri kullanılarak gerçekleştirilen bu çalışmada, öğretmen adaylarının duygu durumları farklı perspektiflerle betimlenmiştir. Elde edilen sonuçlar, bu konuda yapılan ampirik çalışma sayısındaki sınırlılık sebebiyle ağırlıklı olarak kavramsal bakımdan tartışılmıştır.

Araştırmanın ulaştığı sonuçlardan ilki öğretmen adaylarının duygusal fakirlik ya da yoksunluk yaşadıklarıdır. Katılımcıların yarısından fazlası hiç ya da çok az olumlu duygu yaşadığını belirtirken; yaklaşık 3/4’ü olumsuz duyguları hiç ya da çok az yaşadığını belirtmektedir. Öğretmen adayları olumlu duyguları, olumsuz duygulara oranla daha yoğun yaşamalarına karşın her iki tür duygunun yaşanma yoğunluğu çok az kategorisindedir. Robbins ve Judge (2015)'a göre duygular deneyimlere bağlı olarak gelişmektedir. Bu bakımdan, öğretmen adaylarının duygusal yoksunluk içinde olmaları aynı zamanda deneyimsel yoksunluğa da işaret etmektedir. Olumlu ve olumsuz duyguların temelinde kişinin istediği ve istemediği yönde yaşadığı deneyimlerin yattığı bildirilmektedir (Akdoğan, 2016; Ayçiçek, 2012; Baloğlu, 2016; Tarhan, 2006). Bu bakımdan araştırmanın sonucu yorumlandığında katılımcıların istedikleri ve istemedikleri olayları nadiren yaşadıkları söylenebilir. İstenmeyen olayın yaşanmaması fakat istenen olayın daha çok yaşanması arzulanan durumdur. Bu çalışma örneğinde katılımcılar istediklerini gerçekleştirme yönünde sınıllanmış olmalılar. İstedikleri yönünde girişim yapmadıkları çıkarımı da yapılabilir çünkü duygular deneyimlere bağlı yaşandığına göre öğretmen adaylarının bu tür deneyimlere başvurmadıkları anlaşılmaktadır. Argyris (1973) kişilik gelişimine ilişkin olarak insanların olgunlaşma sürecinde pasiflikten etkin olmaya, bağımlılıktan bağımsızlığa, kendi öz farkındalığını geliştirmeye, yüzeysel ilgilerden daha derin ilgilere doğru gelişim gösterdiğini açıklamaktadır. Bu açıklamalar dikkate alındığında çalışmaya katılan öğretmen adaylarının henüz olgunlaşma sürecinin başında oldukları söylenebilir. Onları olgunlaştırabilecek en önemli mekanizmanın öğrenme yaşantıları olduğu dikkate alınırsa eğitim fakültelerindeki öğretimin mercek altına alınması çıkarımı yapılabilir. Öte yandan; çalışmanın bu sonucu Akdoğan (2016), Akçay ve Çoruk (2012) tarafindan ileri sürülen çalışanın duygu durumunun karar almayı, performansı ve başkalarını etkileyebildiği önerisi bağlamında değerlendirilebilir. Bu doğrultuda Askhanasy ve Daus (2015) ani duygusal yaşantıların kişinin içinde bulunduğu durumu rasyonel şekilde analiz etmesini engelleyebildiğini öne sürmektedirler. Öğretmen adaylarında ani duygusal yaşantıya yol açabilecek durumların olmadığı sonucundan hareketle onların rasyonel karar verme açısından uygun koşullara sahip oldukları çıkarımı yapılabilir. Li ve Ahlstrom (2015) tarafindan gerçekleştirilen çalışmada ulaşılan duygusal düzensizliğin ve ani duygusal yaşantıların kişilerin grup içinde çatışma yaşama sıklığını artıracağı ve hayat memnuniyetini düşüreceği sonucu dikkate alındığında öğretmen adaylarının grup içinde çatışma yaşama sıklığının düşük olduğu ve hayatlarından memnun oldukları söylenebilir. Ayrıca Hofstede vd. (2010) tarafından açıklanan beş genel kişilik özelliği (dışa ya da içe dönüklük, tedirgin-endişsli ya da duygusal bakımdan dengeli, uyumlu ya da uyumsuz, bilinçli-aklı başında ya da dengesiz, açık ya da ketum) dikkate alındığında öğretmen adaylarının duygusal bakımdan dengeli kişilik özelliği sergiledikleri belirtilebilir. Bu özelliğin öz saygı (self-esteem) ve akademik başarı ile yüksek düzeyli ilişkiye sahip olduğu bulunmuştur (Chernyshenko vd., 2018). Buradan hareketle öğretmen adaylarının akademik başarı odaklı faaliyetlerinin onların hayatının önemli bir bölümünü kapladığı çıkarımı yapılabilir. Bu çalışmanın bulguları, Argon (2015) tarafından yapılan çalışmanın bulgularıyla da uyumlu olduğu söylenebilir. Anılan çalı̧̧mada ilkokul öğretmenlerinin duygu durumları onların bireysel özelliklerinden etkilendiği gibi yönetsel süreçler, akademik 
etkinlikler ve okul çevresi gibi dışsal değişkenlerden de etkilenmektedir. Gerçek duyguların dişa yansıtılmadığ bu durumun ise onların performansına yansıdığı belirtilmektedir. Ayrıca Frenzel vd. (2017) tarafından önerilen duyguların transferi dikkate alındığında öğretmen adaylarının duygusal transfer gerçekleştirebilecekleri etkileşim düzeyinin de düşük olduğu yorumlanabilir.

Katılımcıların duygu durumu, kültürel tipoloji açısından dinginliğin, coşkusuzluğun tercih edildiği hatta sevinç göstermenin hoş karşılanmadığı doğu kültürünü işaret etmektedir oysa sevinç ve coşku gösterme batı kültüründe teşvik edilen duygu durumlarıdır (Hofstede vd., 2010; Robbins ve Judge, 2015). O’Donovan (2006: 125) sağlıklı bir kültürün özellikleri arasında duygusal ifadelerin teşvik edildiğini ve yönetildiğini belirtir. Çalışmanın bu sonucu Schein (2010) tarafından önerilen duygusal tepkilerin kültürel bir unsur olarak işlevi açısından incelenirse, bazı örgütsel kültürlerde, duygusal davranışın örgütsel normlara aykırı olarak nitelenebildiği ve bu nedenle çalışanların duyguları baskılama yolunu tercih ettikleri durum ile açıklanabilir. Katılımcı öğretmen adaylarının yaşadıkları ortamlardaki egemen normların onların coşkulu, sevinçli, heyecanlı duygu durumlarını desteklemediği söylenebilir. Eğitim fakültesindeki normların da bu kapsamda yer aldığı dikkate alınırsa fakültedeki öğretim uygulamalarının söz konusu duyguları yaşatıcı yönde olmadığı gibi bunun zaten istenmeyen bir durum olduğu çıkarımı da yapılabilir. Bu yargıyı destekleyecek șekilde öğretmen adayları fakültedeki teorik derslerin dıșında MEB'e bağlı okullara uygulama amaçlı gittiklerinde farklı ve heyecan veren duyguları yaşamaktadırlar. Öğretmen adayları için okullarda gözlem yapma, derslere katılma ve hatta ders verme faaliyetleri büyük ölçüde memnuniyetle karşılanmaktadır. Bu memnuniyetin sebeplerinden biri tekdüze, rutinleşen ders etkinliklerinin dışında onlara farklı bir deneyim ve onlar açısından yeni sayılabilecek bir olayın yaşanması olabilir. Bu durum Lunenburg ve Ornstein (2013) tarafından açıklanan öğretmenin sakin, soğukkanlı, öz güvenli olmasıyla; Şişman (2014) tarafından vurgulanan iyi bir öğretmenin coşkulu olması niteliği açısından tartışılabilir. Sosyal-kültürel normlar ile idealize edilen mesleki nitelikler arasındaki uyumsuzluk öğretmenlik mesleğinin duygusal niteliklerinin ne olması gerektiği konusuna da yansımaktadır. Coşkulu, canlı, heyecan veren bir öğretmen mi yoksa sakin, dingin, soğukkanlı bir öğretmen mi? Oysa öğretmen adayları heyecan, coşku ve sevinç gibi duyguları da yaşamak isteyebilir ve bu isteklerini gerçekleştirebilecekleri normların egemen olduğu ortam arayışlarında bulunabilirler ki bu arayış onları eğitim fakültesindeki ortamdan uzaklaştırabilir.

Öğretmen adaylarının en yoğun yaşadıkları duygular merhamet, sevgi ve can sıkıntısıdır. Bu duygular öğretmen adaylarının dışa odaklı, pasif ve hedefsiz olduklarını düşündürmektedir. Aynı zamanda beklentilerini karşılayabilecekleri uygun şartlara sahip olmadıkları, yeni deneyimlere yol açabilecek girişimlerden uzak tek düze bir hayata sahip oldukları yorumu da yapılabilir. Bu yorumu destekleyecek bir başka bulgu katılımcıların içsel duyguları daha düşük yoğunlukta yaşarken dışa yönelik duyguları daha yoğun yaşamalarıdır. Bir başka destekleyici nokta öğretmen adaylarının bir başkasına yönelen bağlılık duygularını daha yoğun yaşarken; bilişsel duyguları daha az yoğun yaşamalarıdır. Bağlılık duygularının (emotional dependence) daha yoğun yaşanması Hofstede vd. (2010: 61) tarafindan otoriter ve babacan kültürlerin bir özelliği olarak bildirilmektedir. Fakat güç mesafesinin fazla olduğu toplumlarda göreli olarak zayıf olanların daha güçlü olanlara yönelik bağlılık duyguları pozitif yönde olabildiği gibi negatif yönde de olabilmektedir. $\mathrm{Bu}$ bakımdan öğretmen adaylarının bağlılık duygularının göreli olarak yüksek olması, Türk toplumunda ağırlıklı olarak güç mesafesinin fazla olmasıyla uyum göstermektedir. Öğretmen adaylarının büyük çoğunluğunun henüz anne-babalarına sosyal ve ekonomik bakımdan bağlı olmaları tahmininden hareketle onların gerek güç mesafesi gerek bağlılık duyguları bakımdan Hofstede vd. tarafından önerilen kültürel sınıflamaya uydukları söylenebilir.

Öğretmen adaylarının olumlu duygu durumu dağılımları incelendiğinde çoğunlukla merhamet duygusu yaşayanlar arasında en az hoşnut olma duygusunun yaşandığı gözlenmektedir. Bu sonuca göre öğretmen adaylarının kendilerine hoşnutluk yaşatabilecek olaylardan büyük ölçüde mahrum oldukları halde; onlara daha yoğunlukla merhamet duygusunu yaşatan kendi durumlarından daha kötü durumda algıladıkları çok daha fazla varlıkla/durumla karşılaştıkları çıkarımı yapılabilir. Bir başka söyleyişle öğretmen adayları kendi durumlarından hoşnut olmasalar da kendilerinden daha kötü durumda olanları daha çok dikkate almaktadırlar. Buna göre öğretmen adaylarında başkalarını fark etme yönünün daha belirgin olduğu söylenebilir. Bununla birlikte merhamet duygusu öne çıktıkça ya da başkalarının durumunu öne çıkardıkça kendi durumlarının üstünü örtmüş de olabilirler.

Olumsuz duygu durumu dağılımlarında ise en yoğun yaşanan duygu durumu can sıkıntısı olarak belirmektedir. Can sıkıntısı, alternatifsizliğin, kararsızlığın, hedefsizliğin, durgunluğun ya da istek ve beklentileri gerçekleştirebilecek koşullara sahip olamamanın göstergesi şeklinde yorumlanabilir. Bu kapsamda öğretmen adaylarının yaşadığı toplumsal, ekonomik, siyasal vb. konularla ilgili duygusal deneyimler onların can sıkıntısı duygusunu daha yoğun yaşamalarına yol açmış olabilir. Üstelik böyle bir durumdan dolayı bir nefret duygusu da neredeyse hiç yaşanmamaktadır. Düşük düzeyde yaşanan nefret duygusu dişa yönelen bir duygu olduğundan öğretmen adaylarının can sıkıntısı duygusundan dolayı kimseyi suçlamadıkları; bu durumun kendi tercihlerinin bir sonucu olduğu söylenebilir. Öğretmen adaylarının mevcut durumlarından memnun olmadıkları ve bu durumu değiştirebilecek uygun koşullara da sahip olmadıkları anlaşılmaktadır. Bu olumsuz duyguyu değiştirme yönünde bir girişimde bulunmadıkları dikkate alındığında öğretmen adaylarının girişime bağlı elde edebilecekleri sonuç 
ilişkisinde kararsız kaldıkları; girişimlerinin maliyeti ile bunun sonucunda elde edebilecekleri sonucun değeri arasında negatif yönlü karara vardıkları ve pasif kalmayı tercih ettikleri çıkarımı yapılabilir. İnsanın olumsuz duyguları yaşamaktan uzaklaşma eğilimi onların zamanla olumsuz duyguları yaşamaktansa bunlara duyarsız kalmaya yöneltebilir. Yani duygusal tepkisizlik durumuyla karşılaş1labilir. Bu durumun önüne geçebilmek amacıyla kurumsal düzeyde öğretmen adaylarının gerçekten nelere ihtiyaç duydukları, neleri bekledikleri ve can sıkıntısına nelerin yol açtığı tespit edilerek çözüm önerileri oluşturulabilir. Onların bireysel olarak cesaret edemedikleri girişimler kurumsal yollarla gerçekleştirilebilir.

$\mathrm{Bu}$ araştırmada katılımcı öğretmen adaylarının duygusal bakımdan henüz öğretmenlik mesleğine hazır olmadıkları sonucuna ulaşılmıştır. Bu sonuç, öğretmenlik mesleğinin gerektirdiği literatürde vurgulanan sosyal ve duygusal yeterliklerin öğrencilerin gelişimiyle ilişkisi (Jennings ve Greenberg, 2009; Nias, 1996; Şişman, 2014) açısından değerlendirildiğinde eğitim fakültelerinde yetiştirme etkinliklerinde düzenlemeler yapılması ihtiyacını ortaya çıkartmaktadır. Yalnızca bilgi edindirmeye yönelik uygulamalar, öğretmen adaylarını tek taraflı donatırken diğer tarafı ihmal edip zayıflatabilmektedir.

Örgütteki yönetim ve liderlik, çalş̧anın performansına olumlu şekilde yansıyabilecek olumlu duygular yaşanmasını sağlayabilir (Töremen ve Çankaya, 2008; Robbins ve Judge, 2015). Bu çalışmanın sonuçlarından hareketle öğretmen adaylarına duygusal canlılık kazandırabilecek etkinliklerin tasarlanması, gerçekleştirilmesi ihtiyacı ortaya çıkmaktadır. Onları sosyal, sanatsal, sportif etkinliklere yönlendirerek duygusal canlılık yaşamaları sağlanabilir. Makro düzeyde ise öğretmenlik eğitimi, öğretmenliğe seçme ve atama süreçlerinde düzenlemeler yapılması ihtiyacı hissedilmektedir. Öğretmen adaylarının can sıkıntısı gibi olumsuz duygularının sebepleri arasında öğretmen atamalarından kaynaklı sorunlar olabilir.

Öğretmen adaylarının olumsuz duygularının sebepleri üzerinde durulması gerekmektedir. Öğretmen adaylarında olumsuz duyguların oluşması, gelişmesi ve devam etmesinin sebepleri yanında; mesleğe girdikten sonra olumsuz duygularının sonuçlarının da olması dikkate alınmalıdır. Bu nedenle öğretmenlik kimliğinin oluşma sürecinin başında, yükseköğretim kademesinde ve mesleğe atanma sürecinde psikolojik durum tespiti, çeşitli araştırma sonuçları temelinde (Skaalvik ve Skaalvik, 2009; Zembylas, 2003) önem taşımaktadır. Öğretmen adaylarının mesleği icra edebilecek duygu durum olgunluğuna sahip olmaları açısından niteliklerini ortaya koymaya yönelik bir çalışma yapılmalıdır. Öğretmen alımlarında ve yönetici görevlendirmelerinde yasal düzenleyici metinlerde (Millî Eğitim Bakanlığı, 2018) ölçütlerden birinin ruhsal bakımdan görevi yapmaya uygunluk oluşturması ve bu durumun daha özenli şekilde raporlanması ve dikkate alınması önerilir. Ayrıca Kyriacou (2001)'nun çalışmasında vurgulandığı üzere; öğretmenlerin olumsuz duygularını azaltmaya yönelik müdahale stratejilerinin belirlenmesi ve bu uygulamaların da etkililiğinin değerlendirilmesi hem uygulama açısından hem de araştırmacılar için fikir vericidir. Bu çalışmadan yararlanarak yapılacak sonraki çalışmalarda katılımcıların belirli bir duyguya ilişkin duygu durumlarının yanı sıra bu duyguları yaşamalarına yol açan durumları örneklendirmeleri istenebilir. Katılımcıların merhamet duygusunu yaşamasına sebep olan bir örnek vermeleri, duygu durumunun incelenmesinde nitel veri sağlayacağından araştırmanın geçerliğini güçlendirecektir. Bu çalışmanın amacı dışında kalan fakat duygu durumlarının incelenmesine katkı sağlayabilecek bir başka öneri ise öğretmenlerin duygu durumlarının onların kurumsal (okul türü, okul kademesi, okul büyüklüğü, okuldaki yönetim tarzı, okulun bulunduğu sosyo-ekonomik çevre vb.) ve bireysel (cinsiyet, yaş, kişilik vb.) özelliklerine göre nasıl değiştiğinin incelenmesidir. $\mathrm{Bu}$ çerçevede öğretmen atamalarından kaynaklı duygusal deneyimlerin toplumsal bağlamda incelendiği bir çalışma da önerilir.

Bu çalışma Orta Anadolu'da yer alan bir devlet üniversitesinin eğitim fakültesinde gerçekleştirilmiştir. İstanbul, Ankara, İzmir gibi büyük ve köklü üniversitelerdeki öğretmen adaylarının duygu durumları farklı olabilir. Mevcut çalışma bahar yarıyılında gerçekleştirilmiştir. Güz döneminde gerçekleştirilebilecek bir çalışmada ulaşılacak sonuçlar değişebilir. Bu çalışma nicel betimlemeyi amaçlamıştır. Nitel yolla (küçük gruplarla, görüşme ve gözlemle) gerçekleştirilebilecek bir çalışmanın sonuçları da farklı olabilir. Bu çalışmanın bir başka sınırlılığı, belirli bir duygu durumun yol açtığı etkileri ihmal etmiş olmasının yanı sıra kavramsal temsiliyet açısından duygu durumu literatür (Cooper ve Sawaf, 2010; Erkuş ve Günlü, 2008) doğrultusunda duygunun yaşanma sıklık ve şiddetinin varyansı olarak işe koşulmuştur. Bu durum sonuçlara yansıyan önemli bir istatistiksel uygulamadır. Sınırlılıklarına rağmen, bu çalışma literatürde tespit edilen araştırma boşluğunu (Akçay ve Çoruk, 2012; Lunenburg ve Ornstein, 2013) gidermede bir katkı olarak nitelenebilir. 


\section{KAYNAKÇA}

Abazoğlu, İ. (2014). Dünyada öğretmen yetiştirme programları ve öğretmenlere yönelik mesleki gelişim uygulamaları. Turkish Studies, 9 (5), 1-46.

Akçay, C. ve Çoruk, A. (2012). Çalışma yaşamında duygular ve yönetimi: Kavramsal bir inceleme. Eğitimde Politika Analiz Dergisi, 1 (1), 3-25.

Akdoğan, E. (2016). Karar verme süreci açısından okul yöneticilerinin duygusal işyüklerini yönetme durumlarının incelenmesi (Yayınlanmamış yüksek lisans tezi). Aksaray Üniversitesi Sosyal Bilimler Enstitüsü, Aksaray.

Argon, T. (2015). Öğretmenlerin sahip oldukları duygu durumlarını okul yöneticilerinin dikkate alıp almamalarına ilişkin görüşleri. Abant İzzet Baysal Üniversitesi Ë̆itim Fakültesi Dergisi, 15(1), 377-404.

Argyris, C. (1973). Personality and organization theory revisited. Administrative Science Quarterly, 18 (2), 141167.

Ashkanasy, N.M.ve Daus, C.S. (2015). The challenge of managing emotions in the workplace. İçinde K.D. Elsbach, A.B. Kayes ve D.C. Kayes (Eds.), Contemporary organizational behavior: From ideas to action (67-77). New York: Pearson.

Avcı, N. (2014). Okul müdürlerinin duygu yönetimi yeterliklerinin çeşitli değişkenlerle incelenmesi ve kişilik özellikleri ile ilişkisi (Yayınlanmamış yüksek lisans tezi). Kocaeli Üniversitesi, Sosyal Bilimler Enstitüsü, Kocaeli.

Ayçiçek, G. (2012). Olumlu ve olumsuz duyguların işgören motivasyonu üzerindeki etkileri ve bir uygulama (Yayınlanmamış Yüksek Lisans Tezi). İnönü Üniversitesi Sosyal Bilimler Enstitüsü, Malatya

Babaoğlan, E., Altun, S. A. ve Çakan, M. (2010). İlköğretim okulu yöneticilerinin tükenmişlik düzeyi. Türk Ĕgitim Bilimleri Dergisi, 8(2), 355-373.

Bakioğlu, A. (2014). Çă̆daş sınıf yönetimi. Ankara: Nobel Yayıncılık.

Baloğlu, N. (2016). Öğretmenlerin örgütsel güven algılarının bazı değişkenler açısından incelenmesi. İçinde Beycioğlu, K., Özer, N., Koşar, D., Şahin, İ. (Edt) Eğitim araştırmaları e-kitap (49-71). Ankara: PegemA.

Başaran, S. (2011) Ortaöğretim kurumlarındaki öğretmen ve yöneticilerin örgütsel güven algılarının belirlenmesi (Yayınlanmamış yüksek lisans tezi). Kırıkkale Üniversitesi, Kırıkkale.

Cemaloğlu, N. ve Şahin, E. D. (2007). Öğretmenlerin mesleki tükenmişlik düzeylerinin farklı değişkenlere göre incelenmesi. Kastamonu Eğitim Dergisi,15(2), 465-484.

Chernyshenko, O., Kankaraš, M. and Drasgow, F. (2018). Social and emotional skills for student success and wellbeing: Conceptual framework for the OECD study on social and emotional skills. OECD Education Working Papers, 173. Paris: OECD Publishing. http://dx.doi.org/10.1787/db1d8e59-en

Cooper, R.K. ve Sawaf, A. (2010). Liderlikte duygusal zekâ (Ayman Z.B. Çev. Ed.). İstanbul: Sistem Yayıncılık.

Çalık, T., Tabak, H. \& Yavuz Tabak, B. (2018). School violence: school administrators' perspectives and ways of solution in Turkey. International Electronic Journal of Elemantary Education, 10(5), 611-620.

Çokluk Bökeoğlu, Ö. ve Yılmaz, K. (2008). İlköğretim okullarında örgütsel güven hakkında öğretmen görüşleri. Kuram ve Uygulamada Eğitim Yönetimi Dergisi,14(2), 211-233.

Çoruk, A. (2012). Yönetim süreçleri açısından yöneticilerin duygu yönetimi davranışları (Yayınlanmamış doktora tezi). On Sekiz Mart Üniversitesi, Çanakkale.

Demir, G. (2013). Kişilerarası iletişimde duygu yönetiminin rolü: Öğretmen-öğrenci iletişimi üzerine bir araştırma (Yayınlanmamış yüksek lisans tezi). Marmara Üniversitesi, İstanbul.

Demirtaş, Z. ve Küçük, Ö. (2016). Öğretmenlerin örgütsel sinizm algıları. İçinde Beycioğlu, K., Özer, N., Koşar, D., Şahin, İ. (Edt) Eğitim araştırmaları e-kitap (180-192). Ankara: PegemA.

Edmondson, A. C., Kramer, R. M. \& Cook, K.S. (2004). Psychological safety, trust, and learning in organizations: A group-level lens. Trust and distrust in organizations: Dilemmas and approaches 12, 239-272.

Eren, E. (2001). Örgütsel davranış ve yönetim psikolojisi. İstanbul: Beta Yayınları.

Erkuş, A. ve Günlü, E.(2008). Duygusal zekânın dönüşümcü liderlik üzerine etkileri. İşletme Fakültesi Dergisi, 9 (2), 187-209.

Evertson, C. M., \& Emmer, E. T. (2013). Illkokul öğretmenleri için sınıf yönetimi. (A. Aypay, çev. ed.). Ankara: Nobel Yayıncilik

Fraenkel, J.R., Wallen, N.E. \& Hyun, H.H. (2012). How to design and evaluate research in education. NY: McGraw-Hill.

Frenzel, A., Becker-Kurz, B., Pekrun, R., Goetz, T., \& Lüdtke, O. (2017). Emotion transmission in classroom revisited: A reciprocal effects modal of teacher and student enjoyment. Journal of Educational Psychology, 110(5), 628-639.

Gasser, L., Grütter, J., Buholzer, A. \& Wettstein, A. (2018). Emotionally supportive classroom interactions and students' perceptions of their teachers as caring and just. Learning and Instruction, 54, 82-92.

Goleman, D. (2011). Duygusal zekâ neden IQ’dan daha önemlidir? İstanbul: Varlık. 
Gök, A. (2016). Bir bağlılık pratiği olarak örgütsel sessizlik. Yönetim ve Ekonomi Araştırmaları Dergisi, 14(1), $104-124$.

Jennings, P. A., \& Greenberg, M. T. (2009). The prosocial classroom: Teacher social and emotional competence in relation to student and classroom outcomes. Review of educational research, 79(1), 491-525.

Jöreskog, K., \& Sörbom, D. (1996). LISREL 8: User's Reference Guide. Chicago: Scientific Software International.

Kahveci, G. ve Demirtaş, Z. (2015). İlkokul, ortaokul ve lise öğretmenlerinin örgütsel sinisizm algılarının incelenmesi. Elektronik Sosyal Bilimler Dergisi, 14(52), 69-85.

Kalağan, G. ve Güzeller, C.O. (2010). Öğretmenlerin örgütsel sinizm düzeylerinin incelenmesi. Pamukkale Üniversitesi Ĕ̈itim Fakültesi Dergisi, 27, 83-97.

Karasar, N. (2008). Bilimsel Araştırma. Ankara: Nobel.

Kervancı, F. (2008). Büro çalışanlarının duygu yönetimi yeterlilik düzeylerinin geliştirilmesinde duygu yönetimi eğitimi programının etkisi (Yayınlanmamış yüksek lisans tezi). Gazi Üniversitesi, Eğitim Bilimleri Enstitüsü, Ankara.

Köse, E. K. (2014). Dezavantajlı okullarda öğretmenlerin örgütsel bağlılıkları ile örgütsel sessizlik arasındaki ilişkiler. Uluslararası Türk Ĕ̈itim Bilimleri Dergisi, 2 (2): 28-36.

Kyriacou, C. (2001). Teacher stress: Directions for future research. Educational review, 53(1), 27-35.

Li, Y. ve Ahlstrom, D. (2016). Emotional stability: A new construct and its implications for individual behavior in organizations. Asia Pacific Journal of Management, 33, 1-28. Doi: 10.1007/s10490-015-9423-2.

Lunenburg, F.C. \& Ornstein, A.C. (2013). Educational Administration [Ĕ̈itim Yönetimi]. (Tran. Ed. G. Arastaman). Ankara: Nobel Yayıncılık. (Original edition 6. Publication year, 2012).

Miller, P. (2012). Ten characteristics of a good teacher. English Teaching Forum, 50(1), 36-38.

Millî Eğitim Bakanlığı (2018). Millî Eğitim Bakanliği Öğretmenlerinin Atama Ve Yer Değiştirme Yönetmeliği http://www.mevzuat.gov.tr/Metin.Aspx?MevzuatKod $=7.5 .9988 \&$ sourceXmlSearch=\&MevzuatIliski $=0$ adresinden $22 / 10 / 2018$ tarihinde alınd .

Morgan, C.T. (2010). Psikolojiye giriş (S. Karakaş ve R. Eski, Çev.). Konya: Eğitim Akademi

Murphy, N. ve Hall, J. (2011). Intelligence and interpersonal sensitivity: A meta-analysis. Intelligence, 39 (1), 5463. http://dx.doi.org/10.1016/j.intell.2010.10.001.

Nias, J. (1996). Thinking about feeling:The emotions in teaching.Cambridge journal of education, 26(3), $293-306$.

O’Donovan, G. (2006). The corporate culture handbook. Dublin: Liffey.

Paker, N. (2009) Illköğretim okulu öğretmenlerinin örgütsel güvenleri ile örgütsel bă̆lllıkları arasındaki ilişki (Sakarya İli Örneği) (Yayınlanmamış yüksek lisans tezi). Sakarya Üniversitesi, Sakarya.

Robbins, S. P. \& Judge, T. A. (2015). Organizational behavior. New Jersey: Pearson

Sarıdede, U. (2016). Öğretim elemanlarının örgütsel bağlılık ile örgütsel sessizlik düzeyleri arasındaki ilişki. İçinde Beycioğlu, K., Özer, N., Koşar, D., Şahin, İ. (Edt) Eğitim araştırmalarl e-kitap (543-552). Ankara: PegemA.

Schein, E. H. (2010). Organizational culture and leadership. San Francisco: Jossey-Bass.

Schenke, K., Ruzek, E., Lam, A.C., Karabenick, S.A. \& Eccles, J.S. (2018). To the means and beyond: understanding variation in students' perceptions of teacher emotional support. Learning and Instruction, $55,13-21$.

Schermelleh-Engel, K., Moosbrugger, H., \& Müller, H. (2003). Evaluating the fit of structural equation models: Tests of significance and descriptive goodness-of-fit measures. Methods of Psychological Research Online, 8(2), 23-74.

Seçer, İ. (2015). SPSS ve LISREL ile pratik veri analizi. Ankara: Anı

Sezer, Ş. (2016). Öğretmenlerin sınıf yönetiminde sergilediği tutumların öğrencilerin gelişimi üzerindeki etkileri: Fenomenolojik bir çözümleme. İçinde Beycioğlu, K., Özer, N., Koşar, D., Şahin, İ. (Edt) Eğitim araştırmaları e-kitap (553-566). Ankara: PegemA.

Skaalvik, E. M., \& Skaalvik, S. (2009). Does school context matter? Relations with teacher burnout and job satisfaction. Teaching and teacher education, 25(3), 518-524.

Sutton, R.E. \& Wheatley, K.F. (2003). Teachers' emotions and teaching: a review of the literature and directions for future research. Educational Psychology Review, 15 (4), 327-358.

Şahin, S., Aydoğdu, B. ve Yoldaş, C. (2011). Duygusal zeka ve iş doyumu arasındaki ilişkiler: Eğitim müfettişleri üzerinde bir araştırma. Ilköğretim Online, 10(3), 974-990.

Şişman, M. (2014). Eğitim bilimine giriş. Ankara: PegemA.

Tabachnick, B. G., \& Fidell, L. S. (2007). Using Multivariate Statistics. Boston: Allyn and Bacon.

Tarhan, N. (2006). Duyguların dili: duygusal zekâya yeni bir yorum. İstanbul: Timaş Yayınları

Yaylac1, G.Ö. (2006). Kariyer yaşamında duygusal zekâ ve iletişim yeteneği "diyalog ve duyguları yönetmek. İstanbul: Hayat Yayıncilik.

Yerlikaya, A. (2008). İsyerlerinde örgütsel adalet algısının duygular üzerindeki etkisi (Yayınlanmamış yüksek lisans tezi). Muğla Sıtkı Koçman Üniversitesi, Eğitim Bilimleri Enstitüsü, Muğla. 
Yıldırım, K.\& Yenipinar, Ş. (2017). Psychological unsafety in schools: The development and validation of a scale. Journal of Education and Training Studies, 5(6), 167-176. doi:10.11114/jets.v5i6.2372.

Yıldırım, K., Tabak, H., \& Yavuz, B. (2012). MEB öğretmen yeterliklerinin kamu personeli seçme sınavı eğitim bilimleri testinde dikkate alınma düzeyi. Türk Ĕ̈itim Bilimleri Dergisi, 10(4), 751-777.

Zembylas, M. (2003). Emotions and Teacher Identity: A poststructural perspective. Journal Teachers and Teaching theory and practice, 9(3), 213-238. 
Ek.

Duygu durum ölçeği

\begin{tabular}{|c|c|c|c|c|c|c|c|c|c|c|}
\hline \multirow[b]{2}{*}{ 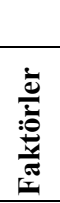 } & \multirow[b]{2}{*}{$\begin{array}{l}\text { No Fakktör } \\
\text { Yükü }\end{array}$} & \multirow[t]{2}{*}{ Duyguyu } & \multicolumn{5}{|c|}{ Yaşama sıklı̆ğ } & \multicolumn{3}{|c|}{ Yaşama şiddeti } \\
\hline & & & $\cong$ & 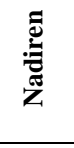 & 芯 & 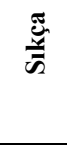 & 竧 & 窇 & ฮ̃ & 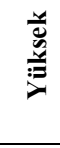 \\
\hline \multirow{9}{*}{ 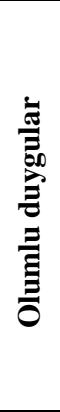 } & $\mathrm{M}_{1.595}$ & Gurur duyma & (1) & (2) & (3) & (4) & (5) & (1) & (2) & (3) \\
\hline & $\mathrm{M}_{2} .617$ & Cesaretlenme & (1) & (2) & (3) & (4) & (5) & (1) & (2) & (3) \\
\hline & $\mathrm{M}_{3} . .641$ & Coşku duyma & (1) & (2) & (3) & (4) & $(5)$ & (1) & (2) & (3) \\
\hline & $\mathrm{M}_{4} .706$ & Hoşnut olma & (1) & (2) & (3) & (4) & (5) & (1) & (2) & (3) \\
\hline & $\mathrm{M}_{5} .683$ & Huzur hissetme & (1) & (2) & (3) & (4) & $(5)$ & (1) & (2) & (3) \\
\hline & $\mathrm{M}_{6} .560$ & Merhamet hissetme & (1) & (2) & (3) & (4) & $(5)$ & (1) & (2) & (3) \\
\hline & $\mathrm{M}_{7} .575$ & Minnet duyma & (1) & (2) & (3) & (4) & $(5)$ & (1) & (2) & (3) \\
\hline & $\mathrm{M}_{8} .718$ & Sevgi hissetme & (1) & (2) & (3) & (4) & (5) & (1) & (2) & (3) \\
\hline & $\mathrm{M}_{9} .492$ & Umutlanma & $(1)$ & (2) & (3) & (4) & $(5)$ & (1) & (2) & (3) \\
\hline \multirow{10}{*}{ 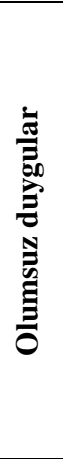 } & $\mathrm{M}_{10.577}$ & Can sikıntıs1 & (1) & (2) & (3) & (4) & (5) & (1) & (2) & (3) \\
\hline & $\mathrm{M}_{11} .697$ & Çaresizlik hissetme & (1) & (2) & (3) & (4) & (5) & (1) & (2) & (3) \\
\hline & $\mathrm{M}_{12 .} .748$ & Hayal kırıklı̆̆ı yaşama & (1) & (2) & (3) & (4) & (5) & (1) & (2) & (3) \\
\hline & $M_{13} .696$ & Kaygılanma & (1) & (2) & (3) & (4) & (5) & (1) & (2) & (3) \\
\hline & $\mathrm{M}_{14.747}$ & Kederlenme & (1) & (2) & (3) & (4) & $(5)$ & (1) & (2) & (3) \\
\hline & $\mathrm{M}_{15} .756$ & Mutsuz olma & (1) & (2) & (3) & (4) & (5) & (1) & (2) & (3) \\
\hline & $\mathrm{M}_{16} .616$ & Nefret hissetme & (1) & (2) & (3) & (4) & (5) & (1) & (2) & (3) \\
\hline & $\mathrm{M}_{17} .572$ & Öfkelenme & (1) & (2) & (3) & (4) & $(5)$ & (1) & (2) & (3) \\
\hline & $\mathrm{M}_{18} .677$ & Ümidini yitirme & (1) & (2) & (3) & (4) & (5) & (1) & (2) & (3) \\
\hline & $\mathrm{M}_{19} .581$ & Yalnızlık hissetme & $(1)$ & (2) & (3) & (4) & $(5)$ & (1) & $(2)$ & (3) \\
\hline
\end{tabular}




\section{EXTENDED ABSTRACT}

\section{Introduction}

As one of the fundamental dynamics of change creates emotions, change is related to the psychological states of individuals (Çalık, 2003). Emotions are the impulses that drive people to take action (Goleman, 2011). Because of the stimuli from the inner and outer environment of the individual, sensation reactions to other people, objects or events around him and his surroundings create reactions (Çoruk, 2012; Kervanc1, 2008). Emotions affect the quality and performance of an individual's decision (Akdoğan, 2016; Li and Ahlstrom, 2016). With administrative interventions, it can be ensured that employees experience emotions that contribute positively to their performance (Robbins and Judge, 2015). In order to be able to manage organizational behaviors, employees should be recognized in terms of their emotions (Akçay and Çoruk, 2012; Lunenburg and Ornstein, 2013). Therefore, it is important to examine the emotions of pre-service teachers in educational institutions. Feelings are the emotional climate of school and class. The emotional identity of a class or a school is a distinctive feature from others. It is reported that teachers who experience negative emotions and reflect them in their actions negatively affect the development of students and schools in various aspects (Çalık, Tabak and Yavuz Tabak, 2018; Demirtaş and Küçük, 2016; Gasser, Grütter, Buholzer and Wettstein, 2018; Schenke, Ruzek, Lam, Karabenick and Eccles, 2018). The contradictory demands of complex work-life relationships can drag individuals into fear and anxiety (Morgan, 2010). Emotional recognition of prospective teachers who will perform the teaching profession in the future is considered important for the function of the profession. Considering the lack of research describing prospective teachers in terms of emotions at national and international level, it was aimed to describe the emotions of teacher candidates in this study. I) to determine the positive and negative emotions of the teacher candidates, ii) the sentimental and outward feelings, iii) the cognitive-loyalty-individual-imaginary-other emotions of emotion and iv) to determine the emotional readiness of the teaching profession sub-objectives have been determined.

\section{Method}

Model of research. Various models such as experiment, interview, observation, case study, video recording, archival review, logging, metaphor use and scanning are used in the studies on the emotional situation (Sutton and Wheatley, 2003). This study, which aims to reveal the emotions of teacher candidates based on the frequency of experiencing the emotion and the frequency of experiencing emotion, is a descriptive study in the screening model. The screening model aims to describe a situation as it exists (Karasar, 2008).

Working group. The study group consisted of prospective teachers enrolled in undergraduate and pedagogical formation programs at Aksaray University Faculty of Education in the 2017-2018 Spring semester. In the study group, which was reached by random sampling, women were represented by $71 \%$. The largest group is science (approximately 40\%) and the least weighted (9\%). The students in the language-based program were about 32\% of the total; The group with religious information has a rate of $19 \%$.

Data collection tool. In this study, a two-part emotion scale was used. The first part of the scale includes demographic information while the second part is aimed at measuring the emotions of the participants. Emotion scale. Empirical and confirmatory factor analyzes of the scale developed by Akdoğan (2016) on the school administrators were carried out.

Data collection process and analysis. The measurement tools were applied between March and April of the 20172018 academic year after obtaining the necessary permits. It was applied in classrooms in the real environments where the participants were collectively. The aim of the study was to determine the positive and negative, inward and outward directed, cognitive-loyalty-individual-imaginary-other emotions of emotion, and the emotional readiness of the teaching profession, mean (x yön), standard deviation (S), frequency (s), frequency ( $f$ ) and percentage $(\%)$ analysis techniques were used.

\section{Findings, Discussion and Results}

In this study which was carried out by using quantitative data analysis techniques, the emotions of teacher candidates were described with different classifications. The results are discussed in terms of conceptuality due to the limited number of empirical studies on this subject.

One of the results of the research is that the pre-service teachers experience emotional poverty or deprivation. More than half of the respondents state that they have little or no positive emotion however, about third of four participants have no or very little negative emotions. Although pre-service teachers experience positive emotions more intensely than negative emotions, the intensity of experience of both types of emotions is very few. It can be deduced from the conclusion that there are no situations that can lead to sudden emotional experiences in teacher 
candidates, and that they have appropriate conditions for rational decision making. The most intense experiences of pre-service teachers are compassion, love and boredom. These feelings suggest that prospective teachers are outward-oriented, passive and non-target. At the same time, it can be said that they do not have the appropriate conditions to meet their expectations and that they have a uniform life away from the attempts that can lead to new experiences. When the positive mood distribution of the trainees is examined, it is observed that the feeling of satisfaction is mostly observed among those who have a sense of compassion. According to this result, although the teacher candidates are largely deprived of events that may cause them satisfaction; they can be deduced that they are faced with a lot more assets / situations that perceive them in a worse condition than their own circumstances, which give them more intense compassion. In the case of negative emotion distributions, the most intense emotional state is boredom. Boredom can be interpreted as an indication of non-alternativeity, instability, lack of goals, stagnation, or lack of conditions to fulfill requests and expectations.

The reasons for the negative emotions of prospective teachers should be emphasized. In addition to the reasons of negative emotions in teacher candidates, development and continuation; After entering the profession, the results of negative emotions should be taken into consideration. A study should be carried out to reveal the qualifications of prospective teachers in terms of having mature status that can perform the profession. It is recommended that one of the criteria in the statutory regulatory texts (Ministry of National Education, 2018) in the recruitment of teachers and in the appointment of administrators is compatible with the task of carrying out the task in a spiritual manner and that this situation should be more carefully reported and taken into account. 